\title{
Empirical Study on Institutional Investors, Free Cash Flow and Corporate Performance
}

\author{
Yong Liang ${ }^{1,2, a}$, Shengdao Gan ${ }^{2}$ \\ ${ }^{1}$ Sichuan Normal University, Sichuan, China \\ ${ }^{2}$ Business School Of Sichuan University, Sichuan, China \\ a3979840@qq.com
}

Keywords: Keywords: institutional investors; free cash flow; performance; shareholder activism

\begin{abstract}
In recent years, the institutional investors play a vital role in corporate governance. Institutional investors have gradually been affirmed of great importance in the company management with the increase of their stake. The problem of free cash flow has caused more and more attention. And it has gradually become an important factor for investors to measure the corporate performance and the development of the company. It is directly related to the significant improvement of the corporate performance that how to perform the institutional investors' shareholder activism and how to strengthen the regulation of free cash flow usage.
\end{abstract}

\section{The Features of Current Sports Media in China}

In recent years, the number of the institutional investors has grown and the shareholder activism of institutional investors has increasingly appeared. The convertible bonds incident of China Merchants Bank, the fund boycott of issuing $\mathrm{H}$ shares of ZTE, the rejected additional motion of Chongqing store reflect the active participation of institutional investors in corporate governance and equity restriction. They also show the institutional investors' unique advantages and strength in corporate governance structure.

\section{Literature Review}

In the modern corporation governance, the separation of ownership and management helps to form the principal-agent relationship between the shareholders and the management. Due to the difference of information asymmetry and the value orientation, it leads to the existence of the contradiction between the shareholders and management goal. Institutional investors rely on the scale advantages of the ownership, the professional technical advantages and the information advantages, so as to avoid internal administrators from manipulating of surplus, supervise and reduce the expropriation of large company shareholders' funds opportunist behavior, reduce shareholder agency cost and improve corporate performance. There are many researches on institutional investors' shareholding and corporate performance at home and abroad. The main aspects are shown in the following.

The view of shareholders participating in the governance. In Berle and Means's (1932) hypothesis [1], after the separation of two rights, it would cause the problem of corporate performance because the company owners and operators hold different opinion on the profit target. As the external stock owners, institutional investors can supervise business decisions and participate in the investment decision. To a certain extent, it helps to ease the contradiction between the differences between shareholders and managers and improve the corporate performance. Kaplan and Stromberg's (2001) [2] research proved that there was a positive correlation between institutional investors and corporate performance. Institutional investors can influence the corporate performance through "vote by hand" and "vote by feet" rights, as well as the volatility of management stock price in capital market, the change of manager market and the regulation of the product or service in product market. 
The view of shareholders' dividend. The dividend is the embodiment of shareholders to obtain investment returns. The dividend distribution is an also objective reflection of the company's performance. Institutional investors prefer dividend distribution to a certain extent. While selecting investment targets and making investment decisions, they tend to obtain long-term dividends as standard. SooJungKim, Wonsik Sul, Shin AE Kang (2010) [3] have found that the dividend distribution policy of institutional investors and corporate influence each other. They were positively correlated. According to statistics, there were 1642 public companies carrying out cash dividend in 2012, accounting for $68 \%$ of the total number of public companies. The cash dividend amount reached $62,980,000$ yuan, accounting for $34.7 \%$ of the net profit.

The view of free cash flow. Since Jansen (1986) put forward the concept of "free cash flow", the problem of corporate performance gradually transit to the free cash flow. Hu Jianping and Gan Shengdao (2007) [4] proposed free cash flow is so large that it may cause the problem of administrators' on-the-job consumption, excessive investment, low efficiency, which lead to the phenomenon of "fat" enterprise cost and the corporate performance continue to decline. Liu Yinguo and Yang Ning's (2012) empirical study found that state-owned holding company left plenty of free cash flow [5]. However, their effective utilization of free cash flow is low, affecting the corporate performance. The medium and small shareholders participating in the enterprise causes high cost of free cash flow high regulation. In terms of the free cash flow, they prefer "free rider", which seriouslyimpacts the company's free cash flow and investment and reutilization benefit.

To sum up, this paper puts forward the following hypothesis:

Hypothesis 1: Free cash flow is positively correlated to corporate performance. If the use efficiency of the free cash flow is not high, it will directly affect the company's future annual performance level.

Hypothesis 2: Institutional investors are negatively correlated to free cash flow. Relying on their professional, scale and the advantages of long-term investment and other characteristics, institutional investors can play a balancing role and enhance the effective use of free cash flow.

Hypothesis 3: The institutional investors and the corporate performance is a positively correlated. To restrict the role of institutional investors in free cash flow, the inefficient use of free cash flow should be prevented in the company management to a certain extent. In this way, it would help to guide to a better and healthy company development combined with the free cash flow, which can also improve the corporate performance.

\section{Research Design}

The data in this paper includes relevant financial data of public companies in manufacturing, collected from China's Shanghai and Shenzhen stock market A strands in 2007-2011. The data were selected in accordance with the following standards: (1) rejecting financial public companies; (2) eliminating the incomplete sample data; (3) eliminating sample firms with the problem of abnormal net profit rate of total assets. Eventually, we got 2145 sample firm records, 425 companies in each year. Data mainly come from the China Tai'an database (CSMAR) and the related data of China securities network. Excel and SPSS 19 were used for data analysis. 
Variable setting

\begin{tabular}{|c|c|c|c|}
\hline Variable & Definition & Calculation formula & Sign \\
\hline \multicolumn{4}{|l|}{1 Dependent variable } \\
\hline $\begin{array}{l}\text { Net profit rate of total } \\
\text { assets } \\
\end{array}$ & $\begin{array}{l}\text { Represents the profitability } \\
\text { of public companies }\end{array}$ & $\begin{array}{c}\text { ROa }=\text { net profit / total assets in } \\
\text { the end of the year* } 100 \%\end{array}$ & Roa or Roat-1 \\
\hline \multicolumn{4}{|l|}{2 Independent variable } \\
\hline $\begin{array}{l}\text { Amount of free cash } \\
\text { flow }\end{array}$ & $\begin{array}{c}\text { The amount of free cash } \\
\text { flow owned by the } \\
\text { company }\end{array}$ & $\begin{array}{c}\text { Fcf }=\text { Net cash flow in } \\
\text { operating activities - the } \\
\text { amount of income tax expense }\end{array}$ & Fcf \\
\hline Institutional investor & & & inst \\
\hline \multicolumn{4}{|l|}{3 Control variable } \\
\hline Growth opportunity & $\begin{array}{c}\text { Having a great effect on } \\
\text { owning the free cash flow } \\
\text { and improve the corporate } \\
\text { performance }\end{array}$ & $\begin{array}{l}\text { Tobin-Q is the variable } \\
\text { business growth opportunities }\end{array}$ & Tobin-Q \\
\hline Assets liability & $\begin{array}{c}\text { Assets liability ratio= } \\
\text { Assets/ liability } * 100 \%\end{array}$ & $\begin{array}{c}\text { Company's financial } \\
\text { development and debt } \\
\text { affordability }\end{array}$ & Lev \\
\hline Company size & $\begin{array}{l}\text { An important index which } \\
\text { bjectively reflecting the } \\
\text { development of the } \\
\text { company }\end{array}$ & $\begin{array}{l}\text { Taking the natural logarithm of } \\
\text { the company's assets }\end{array}$ & Size \\
\hline Cash holdings & $\begin{array}{c}\text { Reflecting company' s } \\
\text { financing trends and its } \\
\text { stock levels of free cash } \\
\text { flow }\end{array}$ & $\begin{array}{l}\text { (Money + short-term } \\
\text { investments) / assets }\end{array}$ & cash \\
\hline GLFYL & $\begin{array}{c}\text { Reflecting company's usage } \\
\text { of free cash flow }\end{array}$ & $\begin{array}{c}\text { GLFYL = Management } \\
\text { expenses / operating income }\end{array}$ & admin \\
\hline Features of the industry & $\begin{array}{l}\text { Reflecting the company's } \\
\text { different sources of cash } \\
\text { flow and performance }\end{array}$ & $\begin{array}{c}\text { Manufacturing industry }=1 \text {; } \\
\text { non-manufacturing sector }=0\end{array}$ & Ind \\
\hline The year of being public & $\begin{array}{l}\text { Reflecting the years of } \\
\text { being public }\end{array}$ & & nf-year \\
\hline
\end{tabular}

\section{Model construction}

Model one: Roa $=\beta_{0}+\beta_{1}$ Fcf $+\beta_{2}$ Tobin $-Q+\beta_{3}$ Lev $+\beta_{4}$ Size $+\beta_{5}$ admin $+\beta_{6}$ cash $+\sum y e a r+\varepsilon$ (1) Model two: $\mathrm{Fcf}=\beta_{0}+\beta_{1}$ Inst $+\beta_{2}$ Tobin $-Q+\beta_{3} \mathrm{Lev}+\beta_{4}$ Size $+\beta_{5}$ admin $+\beta_{6}$ cash $+\sum$ year $+\varepsilon$ (2) Model three: Roa $=\beta_{0}+\beta_{1}$ Instf $+\beta_{2}$ Tobin $-Q+\beta_{3}$ Lev $+\beta_{4}$ Size $+\beta_{5}$ admin $+\beta_{6}$ cash $+\sum$ year $+\varepsilon$ (3)

\section{Specific Empirical Tests}

Descriptive statistic features of the main variables. As shown in Table 1, the proportion of free cash flow in sample firm is 0.04 . The mean score of institutional investor shareholding ratio is 19.31 on average. The proportion of shareholding is relatively low. In China, "a large" capital market is a normal phenomenon. In manufacturing industry, performance of the year is equal to that of the following year, which shows the steady development and relatively stable performance. 
Table 1 Description of the main variables

\begin{tabular}{c|c|c|c|c|c}
\hline & $\begin{array}{c}\text { Sample } \\
\text { quantity }\end{array}$ & Minimum & Maximum & Mean & SD \\
\hline $\begin{array}{c}\text { Performance of the } \\
\text { following year }\end{array}$ & 2145 & -2.75 & 2.57 & .037 & .12 \\
\hline $\begin{array}{c}\text { Performance of the year } \\
\text { Free cash flow }\end{array}$ & 2145 & -2.75 & 2.57 & .04 & .125 \\
\hline $\begin{array}{c}\text { Institutional investor } \\
\text { shareholding ratio }\end{array}$ & 2145 & -1.67 & .46 & 19.31 & 18.996 \\
\hline Tobin-Q & 2145 & .00 & 100.00 & & .08 \\
\hline Assets liability & 2145 & .007 & 6.740 & .504 & .365 \\
\hline Company size & 2145 & 16.93 & 26.16 & 21.43 & 1.25 \\
\hline GLFYL & 2145 & .005 & 7.714 & .093 & .227 \\
\hline Cash holdings & 2145 & .0002 & .997 & .1716 & .120 \\
\hline Effective N & 2145 & & & & \\
\hline
\end{tabular}

Regression analysis. As shown in the results of Model (1), in 2007-2011, the domestic manufacturing companies' free cash flow (fcf) and their net profit of the year and the following year were significantly and positively correlated at a significance level of 0.005 . And the regression coefficient is 0.115 , which shows a positive correlation between the amount of the free cash flow and the corporate performance. If the free cash flow is larger, the company's operating cash flow and its corporate profits would be. At the same time, the company free cash flow will have a positive effect on the corporate performance of the year, which is a manifestation of the profit cumulative effect.

Model 1 Regression results

\begin{tabular}{|c|c|c|c|c|c|}
\hline & \multicolumn{2}{|c|}{$\begin{array}{c}\text { Unstandardized } \\
\text { Coefficient }\end{array}$} & \multirow{2}{*}{$\begin{array}{c}\begin{array}{c}\text { Standard } \\
\text { coefficient }\end{array} \\
\text { Trial } \\
\end{array}$} & \multirow[b]{2}{*}{$\mathrm{t}$} & \multirow[b]{2}{*}{ Sig. } \\
\hline & $\mathrm{B}$ & SD & & & \\
\hline (Constant) & -.188 & .050 & & -3.766 & .000 \\
\hline Free cash flow & .115 & .031 & .079 & 3.691 & .000 \\
\hline Tobin-Q & .009 & .002 & .132 & 5.443 & .000 \\
\hline Assets liability & -.076 & .008 & -.223 & -9.714 & .000 \\
\hline Company size & .011 & .002 & .115 & 4.926 & .000 \\
\hline GLFYL & -.021 & .012 & -.038 & -1.763 & .078 \\
\hline Cash holdings & .089 & .023 & .085 & 3.837 & .000 \\
\hline The year of being public & -.002 & .001 & -.067 & -2.950 & .003 \\
\hline
\end{tabular}

a. Dependent variable: Performance of the following year

From the test results of Model (2), we can find that the free cash flow of the company (FCF) has a positive correlation with the proportion of institutional investors holding below 0.1 , which was relatively weak. The main reason is that the phenomenon of "alone big" in China's public companies is quite serious. In manufacturing companies, most of them are original state-owned enterprise. There are many state-owned holding companies. Therefore, the proportion of institutional investors is quite limited. 
Model 2 Regression results

\begin{tabular}{|c|c|c|c|c|c|}
\hline & \multicolumn{2}{|c|}{$\begin{array}{c}\text { Unstandardized } \\
\text { Coefficient } \\
\end{array}$} & \multirow{2}{*}{$\begin{array}{c}\begin{array}{c}\text { Standard } \\
\text { coefficient }\end{array} \\
\text { Trial } \\
\end{array}$} & \multirow[b]{2}{*}{$\mathrm{t}$} & \multirow[b]{2}{*}{ Sig. } \\
\hline & $\mathrm{B}$ & SD & & & \\
\hline (Constant) & -.071 & .035 & & -2.024 & .043 \\
\hline $\begin{array}{c}\text { Institutional investor } \\
\text { shareholding ratio }\end{array}$ & .000 & .000 & .036 & 1.725 & .085 \\
\hline Tobin-Q & -.003 & .001 & -.059 & -2.433 & .015 \\
\hline Assets liability & -.042 & .005 & -.179 & -7.850 & .000 \\
\hline Company size & .005 & .002 & .071 & 2.866 & .004 \\
\hline GLFYL & -.004 & .008 & -.011 & -.484 & .628 \\
\hline Cash holdings & .124 & .016 & .172 & 7.790 & .000 \\
\hline Number of the board & .003 & .002 & .066 & 1.589 & .112 \\
\hline $\begin{array}{c}\text { Number of independent } \\
\text { directors } \\
\end{array}$ & -.007 & .004 & -.069 & -1.675 & .094 \\
\hline Number of supervisors & $-4.321 \mathrm{E}-5$ & .002 & -.001 & -.028 & .978 \\
\hline The year of being public & .001 & .000 & .068 & 2.957 & .003 \\
\hline
\end{tabular}

a. Dependent variable: Free cash flow

Model (3) reflects there was a positive correlation between institutional investor shareholding ratio (Inst) and corporate performance of the year in manufacturing at a significance level of 0.05 . And there was a positive correlation between institutional investor shareholding ratio (Inst) and the corporate performance of the following year, but the correlation is not strong. At the same time, this paper also detected institutional investor shareholding ratio (Inst) and free cash flow (FCF) between cross coefficient and manufacturing corporate performance levels. The study also found that the cross coefficient and corporate performance of the year have a positive correlation below 0.01 and the correlation is significant, which shows that they have great influence on the corporate performance. The cross correlation coefficient of the corporate performance of the following year is also positively correlated below 0.05 .

Model 3-1 Regression results

\begin{tabular}{|c|c|c|c|c|c|}
\hline & \multicolumn{2}{|c|}{$\begin{array}{c}\text { Unstandardized } \\
\text { Coefficient } \\
\end{array}$} & \multirow{2}{*}{$\begin{array}{c}\begin{array}{c}\text { Standard } \\
\text { coefficient }\end{array} \\
\text { Trial } \\
\end{array}$} & \multirow[b]{2}{*}{$\mathrm{t}$} & \multirow[b]{2}{*}{ Sig. } \\
\hline & $\mathrm{B}$ & $\mathrm{SD}$ & & & \\
\hline (Cash holdings) & -.218 & .050 & & -4.369 & .000 \\
\hline $\begin{array}{l}\text { Institutional investor } \\
\text { shareholding ratio }\end{array}$ & .000 & .000 & .045 & 2.178 & .030 \\
\hline Assets liability & -.082 & .008 & -.241 & $\begin{array}{r}-10.70 \\
6 \\
\end{array}$ & .000 \\
\hline Company size & .014 & .002 & .143 & 5.832 & .000 \\
\hline Tobin-Q & .008 & .002 & .121 & 5.021 & .000 \\
\hline Cash holdings & .105 & .023 & .101 & 4.600 & .000 \\
\hline Number of the board & .000 & .002 & -.002 & -.049 & .961 \\
\hline $\begin{array}{c}\text { Number of } \\
\text { independent directors }\end{array}$ & -.005 & .006 & -.032 & -.787 & .431 \\
\hline Number of supervisors & -.004 & .002 & -.038 & -1.679 & .093 \\
\hline $\begin{array}{c}\text { The year of being } \\
\text { public }\end{array}$ & -.002 & .001 & -.062 & -2.700 & .007 \\
\hline
\end{tabular}


a. Dependent variable: Performance of the year

Model 3-2 Regression results

\begin{tabular}{|c|c|c|c|c|c|}
\hline & \multicolumn{2}{|c|}{$\begin{array}{c}\text { Unstandardized } \\
\text { Coefficient }\end{array}$} & \multirow{2}{*}{$\begin{array}{c}\begin{array}{c}\text { Standard } \\
\text { coefficient }\end{array} \\
\text { Trial } \\
\end{array}$} & \multirow[b]{2}{*}{$\mathrm{t}$} & \multirow[b]{2}{*}{ Sig. } \\
\hline & $\mathrm{B}$ & $\mathrm{SD}$ & & & \\
\hline (Cash holdings) & -.167 & .051 & & -3.284 & .001 \\
\hline $\begin{array}{c}\text { Institutional investor } \\
\text { shareholding ratio }\end{array}$ & .000 & .000 & .020 & .926 & .354 \\
\hline Assets liability & -.030 & .008 & -.089 & -3.849 & .000 \\
\hline Company size & .010 & .002 & .099 & 3.950 & .000 \\
\hline Tobin-Q & .006 & .002 & .095 & 3.847 & .000 \\
\hline Cash holdings & .155 & .023 & .150 & 6.666 & .000 \\
\hline Number of the board & .001 & .002 & .018 & .426 & .670 \\
\hline $\begin{array}{c}\text { Number of } \\
\text { independent directors }\end{array}$ & -.007 & .006 & -.047 & -1.117 & .264 \\
\hline Number of supervisors & -.003 & .002 & -.029 & -1.244 & .214 \\
\hline $\begin{array}{c}\text { The year of being } \\
\text { public }\end{array}$ & -.001 & .001 & -.046 & -1.951 & .051 \\
\hline
\end{tabular}

a. Dependent variable: Performance of the following year

\section{Conclusions and Suggestions}

We can find that the free cash flow of company stock has a dual character. On one hand, it can evaluate and measure the corporate performance by using free cash flow index. If the company operates well, its net cash flow and free cash flow would be adequate. On the other hand, the effective use of the company's free cash flow will also affect the company's future performance levels. Through the refinancing of free cash flow and the regeneration of capital usage efficiency, it would bring new inflow of funds for the development of the company and improve corporate performance. Institutional investors have the dual effects of the internal balance in public companies and the external governance. They have certain restriction on large shareholders and company management layers. However, based on the particularity of domestic capital market and the development level of public companies, this kind of "Shareholder Activism" is affected by the multi surface factors. The institutional investors can hardly fully play their unique professional management ability. Therefore, we should actively develop and enlarge the size of the institutional investors, which are still an important task to regulate and improve China's capital market and corporate governance.

\section{Acknowledgements}

Fund project: Supported by National Social Science Fund. One achievement of the project, Financial fair estimating research on employees' earnings and capital return in public company (13BJY015). Supported by National Natural Science Foundation of China, Perform change of domestic public companies - Based on free cash flow (70672013).

\section{References}

[1] Berle.A, Means.G, he Modern Corporation and Private Property[M].New York:The Comerce Clearing House,1932.

[2] Kaplan, steven N,Stromberg,Perventure Capitalists as Principals:Contracting Screening,and Monitoring[J],Aerican Economic Review,2001,(2). 
[3] SooJung Kim, Wonsik Sul,Shin AE Kang, Impact of foreign institutional investors on dividend policy in Korea:A stock market perspective[J].Journal of Management and Analysis,2010(4).

[4] Hu Jianping, Gan Shengdao. Too Much Money may Cause Damage: Free Cash Flow and Overinvestment [J] CONTEMPORARY FINANCE \& ECONOMICS. NO.11, 2007

[5] Liu Yinguo, Yang Ning. Correlation study Between Free Cash Flow, Corporate Governance and Corporate performance [J].Friends of Accounting. 2012, (6). 